\title{
PENERAPAN PENDEKATAN REALISTIC MATHEMATICS EDUCATION (RME) MELALUI PERANGKAT PEMBELAJARAN TERHADAP MOTIVASI BELAJAR MATEMATIKA SISWA
}

\author{
${ }^{1}$ Fidi Dwi Anita \\ ${ }^{1}$ Pendidikan Matematika, Fakultas Keguruan dan Ilmu Pendidikan, Universitas Muhammadiyah \\ Sukabumi dwianitafidi@gmail.com
}

\begin{abstract}
Abstrak
Tujuan dari penelitian ini untuk mendeskripsikan kegiatan pembelajaran dengan menerapkan pendekatan Realistics Mathematics Education melalui perangkat pembelajaran seperti RPP dan LKS yang diharapkan dapat meningkatkan motivasi belajar matematika siswa. Metode penelitian yang digunakan dalam penelitian ini adalah metode kualitatif dengan jenis penelitian kepustakaan. Berdasarkan hasil penelitian tersebut maka dapat disimpulkan bahwa penerapan pendekatan RME melalui perangkat pembelajaran seperti RPP dan LKS dapat meningatkan motivasi belajar matematika siswa. LKS yang dibuat relavan dengan kehidupan nyata dari masalah kontekstual pada LKS dilengkapi dengan gambargambar, sehingga membantu siswa memahami apa yang mereka temui. Melalui kegiatan mendiskusikan dan membandingkan jawaban, siswa dilatih berbicara, bertanya serta berdiskusi mengenai materi agar membuat siswa berkembang. Dan melalui kegiatan mempresentasikan hasil diskusi, siswa dapat meningkatkan kepercayaan diri sehingga mereka memiliki motivasi serta semangat dalam belajar matematika.
\end{abstract}

Kata kunci: realistic mathematics education, motivasi belajar, perangkat pembelajaran

\section{PENDAHULUAN}

Matematika merupakan ilmu pasti. Ilmu pengetahuan yang mengajarkan untuk berpikir logis dan sistematis. Matematika memiliki peranan penting untuk menjawab berbagai macam permasalahan yang terjadi pada kehidupan sehari-hari. Oleh karena itu, matematika menjadi salah satu mata pelajaran pokok yang diajarkan diberbagai jenjang pendidikan, selain itu matematika termasuk mata pelajaran dalam ujian nasional. Pembelajaran matematika merupakan interaksi antara guru yang mengajarkan matematika dan siswa yang menerima ilmu matematika. Dalam kegiatan pembelajaran peranan guru dan siswa sangat penting agar tujuan pembelajaran yang telah ditetapkan tercapai.

Kenyataannya masih rendah motivasi siswa dalam belajar matematika. Siswa menganggap bahwa matematika hanya sekadar membahas tentang simbol dan angka, siswa juga beranggapan bahwa matematika adalah mata pelajaran yang sulit dan guru yang mengajarkan matematika memiliki mimik wajah yang cukup serius. Selain itu siswa belum memiliki dorongan untuk belajar matematika. Siswa memiliki caranya sendiri untuk mengalihkan perhatian selama proses pembelajaran, seperti menggambar dan mencoret-coret dibuku catatan, mengobrol dengan teman sebangku, dan terdapat beberapa siswa memilih duduk di belakang agar dapat tidur ketika pembelajaran berlangsung. Pendekatan pembelajaran yang diterapkan menjadi permasalahan dalam hal tersebut karena guru belum mampu membuat siswa termotivasi dalam belajar matematika. Pembelajaran yang membosankan dan menjadikan siswa pasif, karena guru hanya menjelaskan materi kemudian memberikan latihan soal untuk dikerjakan oleh siswa. Berdasarkan kondisi berikut peneliti menilai bahwa rendahnya motivasi belajar matematika siswa disebabkan guru yang belum mampu dalam memiilih pendekatan pembelajaran yang sesuai dengan siswa dan kesan yang diberikan guru terhadap siswa.

Motivasi menjadi hal penting bagi siswa. Jika siswa diberikan dorongan dalam belajar, maka tujuan pembelajaran yang ditetapkan akan tercapai. Berdasarkan Uno (2013) motivasi adalah kekuatan, baik dari dalam maupun dari luar yang mendorong seseorang 
untuk mencapai tujuan tertentu yang telah ditetapkan sebelumnya. Motivasi yang diberikan akan mempengaruhi keberhasilan siswa dalam belajar.

Sifat motivasi terdiri atas dua, yaitu motivasi intrinsik dan motivasi ekstrinsik. Motivasi intrinsik merupaka motivasi yang melibatkan diri dalam suatu aktivitas karena nilai atau manfaat dari aktivitas itu sendiri. Sehingga seseorang akan termotivasi secara intrinsik mengerjakan aktivitas karena aktivitas tersebut menyenangkan. Sedangkan motivasi ekstrinsik merupakan motivasi yang melibatkan diri dalam suatu aktivitas sebagai cara untuk mencapai tujuan. Sehingga sesorang akan termotivasi secara ekstrinsik mengerjakan aktivitas karena menyakini bahwa dengan berpartisipasi dalam aktivitas tersebut akan menyebabkan tujuannya tercapai, seperti mendapatkan hadiah atau terhindar dari hukuman (Schunk, et, al : 2012).

Salah satu upaya yang dilakukan untuk meningkatkan motivasi belajar matematika siswa yaitu dengan menerapkan pendekatan pembelajaran yang berkaitan dengan kehidupan nyata. Realistic Mathematics Education (RME) menjadi alternative pendekatan pembelajaran dalam meningkatkan motivasi belajar matematika siswa dan diharapkan membuat siswa mengetahui manfaat dari matematika yang telah dipelajari. Realistic Mathematics Education dikembangkan di Belanda sejak tahun 1970 berdasarkan ide dari Freudenthal yang mengatakan bahwa matematika adalah aktivitas manusia dan pembelajarannya dimulai dengan masalah-masalah yang dapat dibayangkan oleh siswa. Dimana dalam kegiatan belajar guru mengajar tidak langsung memberikan informasi, tetapi harus menciptakan aktivitas yang dapat digunakan siswa untuk mengkontruksi pengetahuan matematika. Ada tiga prinsip utama di dalam RME (Gravemeijer, 1994), yaitu : (1) penemuan kembali secara terbimbing (guided reinvention) dan matematisasi progresif (progressive mathematization); (2) fenomenologi didaktis (didactical phenomenology); dan (3) mengebangkan modelmodel sendiri (self-developed models). Selain itu, terdapat lima karakteristik RME (Treffers, 1987; Bakker, 2004), yaitu (1) phenomenological exploration; (2) using models and symbols for progressive mathematization; (3) using students' own construction and productions; (4) interactivity; dan (5) intertwinement. Langkah-langkah RME yaitu: (1) memahami masalah konstektual; (2) menjelaskan masalah konstektual; (3) menyelesaikan masalah; (4) membandingkan dan mendiskusikan jawaban; dan (5) menyimpulkan.

Penelitian ini bertujuan untuk mendeskripsikan kegiatan pembelajaran dengan penerapan pendekatan Realistic Mathematics Education (RME) melalui perangkat pembelajaran (RPP dan LKS) untuk meningkatkan motivasi belajar matematika siswa.

\section{METODE PENELITIAN}

Metode penelitian yang digunakan dalam penelitian ini adalah metode kualitatif dengan jenis penelitian kepustakaan. Penelitian kepustakaan merupakan suatu jenis penelitian yang digunakan dalam pengumpulan informasi dan data secara mendalam melalui berbagai literatur, buku, catatan, serta hasil penelitian sebelumnya yang relevan, untuk mendapatkan jawaban dan landasan teori mengenai masalah yang akan diteliti.

\section{HASIL DAN PEMBAHASAN}

Menurut Permendikbud Nomor 65 Tahun 2013 tentang Standar Proses, Rencana Pelaksanaan Pembelajaran (RPP) merupakan suatu rencana kegiatan pembelajaran tatap muka untuk satu pertemuan atau lebih. RPP berkemang dari silabus untuk lebih mengarakan kegiatan pembelajaran peserta didik untuk mencapai Kompetensi Dasar. Trianto (2008: 148) mendefinisikan bahwa Lembar Kerja Siswa (LKS) adalah panduan siswa yang digunakan untuk melakukan kegiatan penyelidikan dan pemecahan masalah. 

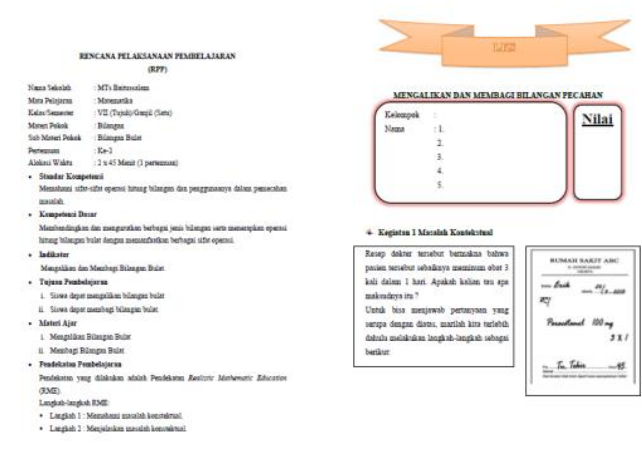

Gambar 1. Layout RPP dan LKS

Dari gambar 1 dapat dilihat bahwa dengan menerapkan pendekatan RME melalui RPP dan LKS diharapkan siswa akan terbantu dalam kegiatan pembelajaran matematika agar tidak cepat bosan dan siswa aktif selama kegiatan pembelajaran berlangsung. Selain itu, mulai tumbuh dorongan untuk belajar matematika. RPP dengan menerapkan pendekatan RME sama saja dengan RPP pada umumnya, hanya saja RPP dengan pendekatan RME terdapat langkahlangkah dan karakteristik RME yang harus dilalui siswa dan guru selama kegiatan pembelajaran dengan harapan tujuan pembelajaran dapat tercapai.

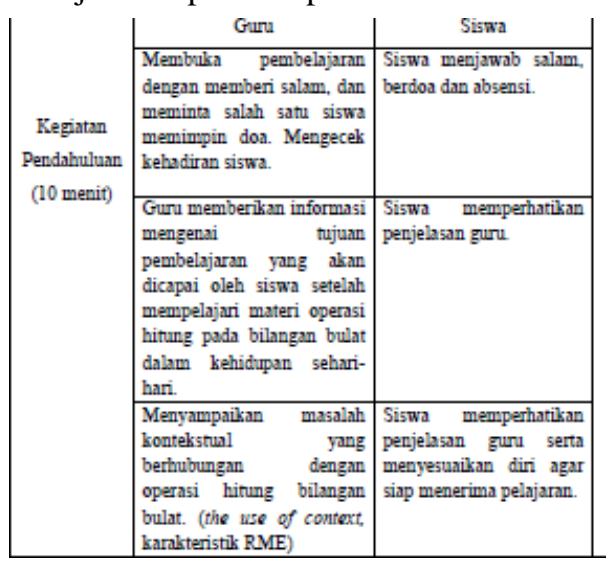

Gambar 2. RPP Bagian Kegiatan Pendahuluan

Pada kegiatan pendahuluan, guru memberi salam dan meminta salah satu siswa untuk memimpin doa. Kemudian guru menjelaskan mengenai tujuan pembelajaran yang akan dicapai oleh siswa setelah mempelajari materi tersebut. Bagian ini terdapat karakteristik RME yaitu the use of context atau phenomelogical explration dimana guru menyampaikan masalah kontekstual yang berhubungan dengan materi yang diajarkan.

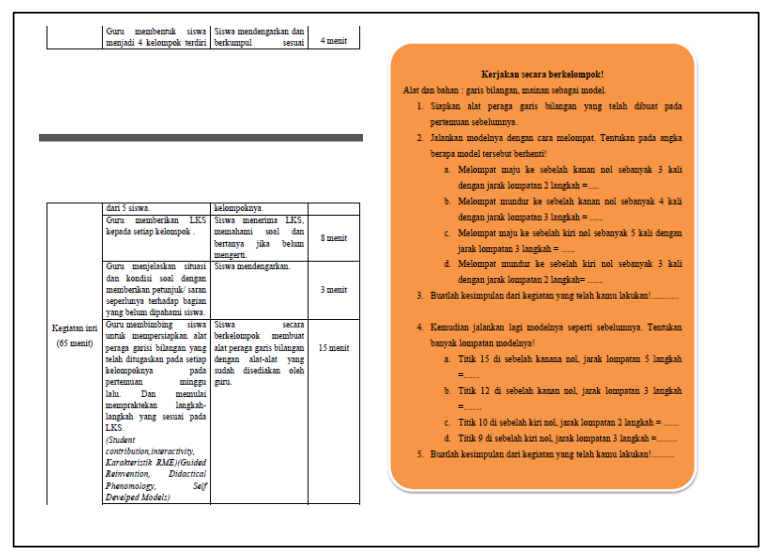

Gambar 3. Rpp Bagian Kegiatan Inti dan LKS

Sebelum kegiatan pembelajaran berlangsung, guru membagi siswa dengan 4 kelompok yang terdiri dari 5 orang siswa dan guru memberikan informasi kepada siswa bahwa akan ada kelompok terbaik yaitu dengan kriteria kelompok tersebut aktif berpendapat dan bertanya, kompak, serta tampil di depan kelas dengan percaya diri, kecepatan serta ketepatan menyelesaikan tugas. Kelompok yang memenuhi kriteria tersebut akan mendapat hadiah dari guru. Tindakan tersebut dilakukan agar siswa fokus selama kegiatan pembelajaran dan memotivasi siswa melalui pendekatan RME. Pada bagian ini terdapat karateristik RME yaitu using students' own construction and productions dan interactivity, serta terdapat prinsip RME yaitu, penemuan kembali secara terbimbing dan matematisasi progresif; fenomenologi didaktis; dan mengebangkan model-model sendiri. Dimana guru membimbing siswa untuk mempersiapkan alat peraga pada setiap kelompoknya dan mulai mempraktekkan langkah-langkah yang terdapat pada LKS. 


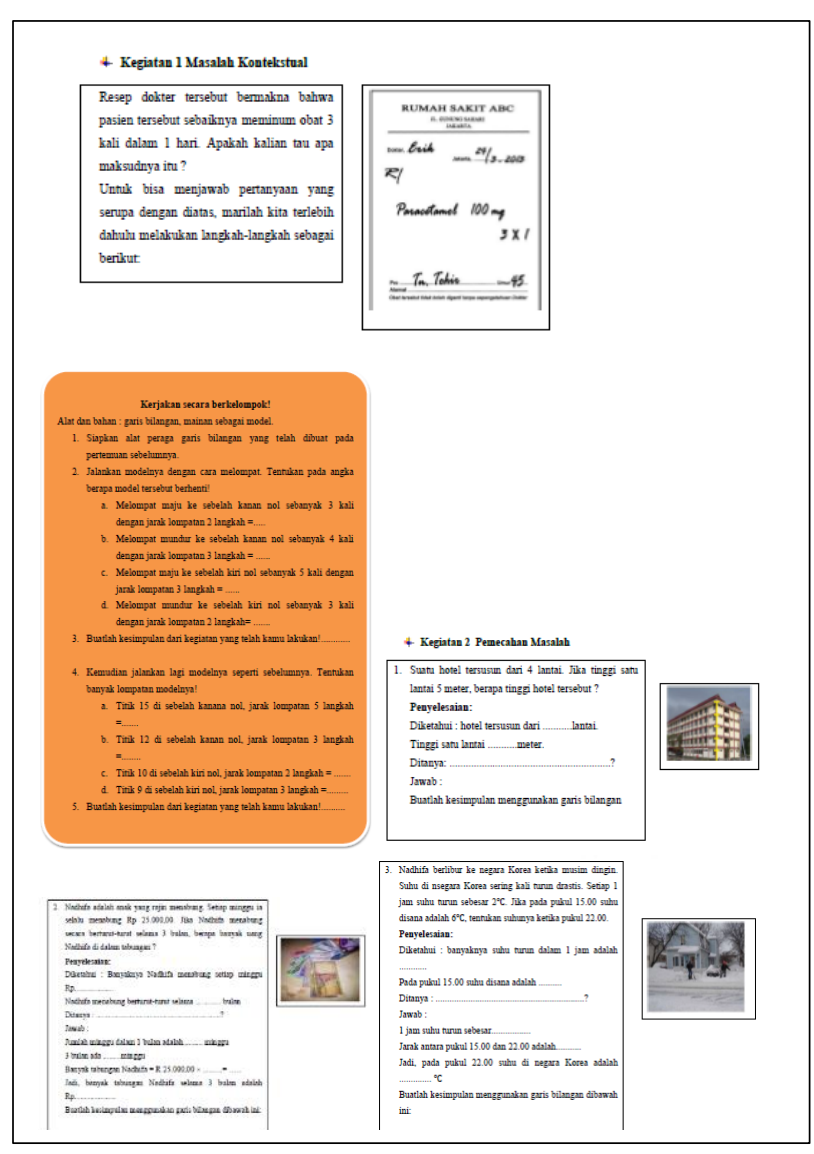

Gambar 4. Kegiatan Masalah Kontekstual dan Pemecahan Masalah

Upaya dalam meningkatkan motivasi belajar matematika siswa yaitu dengan penerapan pendekatan RME. Terdapat langkahlangkah yang harus dilalui oleh siswa yang pertama, memahami masalah kontekstual. Guru memberikan LKS kepada siswa dan meminta siswa untuk menyelesaikan masalah dalam LKS. Masalah kontekstual yang disajikan dalam LKS dilengkapi dengan gambar agar membantu siswa memahami apa yang ditemukan dalam kehidupan nyata. Kedua, menjelaskan masalah. Guru memberikan arahan kepada siswa dalam menyelesaikan permasalahan. Saat menanggapi siswa, hendaknya guru menghargai mereka dengan kata-kata positif serta memberikan ekspresi mimik wajah yang menyenangkan. Tindakan guru ketika menanggapi pertanyaan atau pernyataan siswa dengan positif tanpa menyalahkan akan mempengaruhi motivasi belajar matematika siswa serta kepercayaan diri siswa. Mimik wajah serta pujian menjadi pengaruh untuk meningkatkan motivasi belajar matematika siswa. Ketiga, menyelesaikan masalah kontekstual. Guru membantu siswa dengan cara memberikan langkah-langkah atau petunjuk pada LKS untuk menemukan konsep serta penyelesaian dari masalah kontekstual agar siswa tidak bingung ketika mulai mengerjakan. Dengan adanya kegiatan berupa LKS dapat memberi motivasi kepada siswa dalam menyelesaikan suatu masalah.

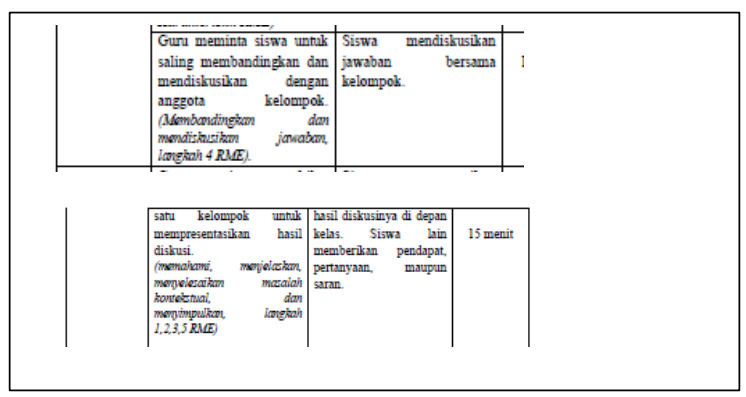

Gambar 5. Langkah Ke 4 RME

Langkah keempat, membandingkan dan mendiskusikan jawaban. Guru meminta siswa untuk saling membandingkan dan mendiskusikan jawaban antar anggota kelonpok dan dengan kelompok lain. Dengan adanya kegiatan diskusi kelas, cara berbicara atau komunikasi siswa akan berkembang. Selain itu, cara mendengarkan, bertanya, serta cara berdiskusi mengenai materi yang dipelajari akan membuat siswa berkembang (Schunck, et, al: 2012). Kemudian guru meminta perwakilan kelompok untuk mempresentasikan hasil diskusi. Awalnya siswa merasa cemas untuk tampil di depan kelas, namun guru memberikan arahan dan kata-kata positif kepada siswa agar termotivasi. Pada akhirnya siswa berani berbicara dan mampu menjelaskan langkahlangkah atau kosep dari jawabannya. 


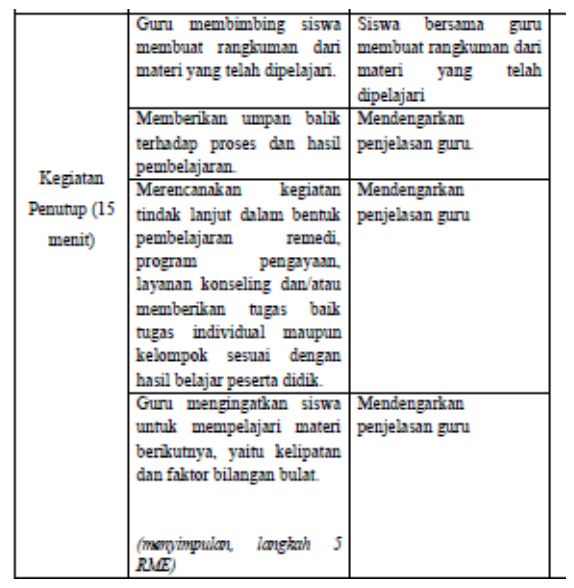

Gambar 6. Langkah 5 RME

Langkah kelima dari pendekatan RME yaitu menyimpulkan. Guru membimbing siswa untuk membuat rangkuman dari materi yang telah dipelajari dan memberikan pertanyaan yang memancing siswa berpendapat maupun bertanya. Sebagian siswa mulai berani menyampaikan pendapat dan merangkum materi dengan teratur. Kemudian, guru mengumumkan kelompok terbaik dari pertemuan kali ini dan memberikan hadiah serta pujian kepada mereka. Tindakan tersebut bertujuan agar siswa termotivasi untuk lebih giat belajar pada pertemuan berikutnya. Sebelum menutup pertemuan, guru mengingatkan siswa untuk mempelajari materi pada pertemuan berikutnya.

\section{SIMPULAN}

Berdasarkan hasil penelitian tersebut maka dapat disimpulkan bahwa penerapan pendekatan RME melalui perangkat pembelajaran seperti RPP dan LKS dapat meningatkan motivasi belajar matematika siswa. LKS yang dibuat relavan dengan kehidupan nyata dari masalah kontekstual pada LKS dilengkapi dengan gambar-gambar, sehingga membantu siswa memahami apa yang mereka temui. Melalui kegiatan mendiskusikan dan membandingkan jawaban, siswa dilatih berbicara, bertanya serta berdiskusi mengenai materi agar membuat siswa berkembang. Dan melalui kegiatan mempresentasikan hasil diskusi, siswa dapat meningkatkan kepercayaan diri sehingga mereka memiliki motivasi serta semangat dalam belajar matematika.

\section{REKOMENDASI}

Dari hasil penelitian ini diharapkan dapat digunakan sebagai alternatif dalam meningkakan motivasi belajar siswa sehingga kualitas pembelajaran matematika di sekolah akan lebih baik.

\section{DAFTAR RUJUKAN}

Afriansyah, E.A. 2006. Makna Realistic dalam RME dan PMRI. Garut: STKIP Garut.

Marini,. As'ari A.R., dan Chandra T.D. 2007. Peningkatkan Motivasi Belajar Siswa Melalui Penerapan Pendekatan Realistic Mathematics Education $(R M E)$. Malang: Universitas Negeri Malang.

Marpaung, Y., dan Julie H. PMRI dan PISA: Suatu Usaha Peningkatan Mutu Pendidikan Matematika di Indonesia (makalah). 